\title{
Dynamic analysis of Th1/Th2 cytokine concentration during antiretroviral therapy of HIV-1/HCV co-infected Patients
}

\author{
Wenzhen Kang ${ }^{* \dagger}$, Yuan $\mathrm{Li}^{\dagger}$, Yan Zhuang, Ke Zhao, Dedong Huang and Yongtao Sun ${ }^{*}$
}

\begin{abstract}
Background: Co-infection with hepatitis $\mathrm{C}(\mathrm{HCV})$ is very common in human immunodeficiency virus 1 (HIV-1) infected patients. Although HIV co-infection clearly accelerates progression of HCV-related fibrosis and liver disease, controversy remains as to the impact of HCV on HIV disease progression in co-infected patients. HIV can cause immune dysfunction, in which the regulatory function of T helper (Th) cells is very essential. Moreover, cytokines derived from Th cells play a prominent role in viral infection. Investigating the functional changes of Th1 and Th2 cells in cytokine level can improve the understanding of the effect of co-infected HCV on HIV infection.
\end{abstract}

Methods: In this study, we measured the baseline Th1/Th2 cytokine concentration in sera by using flow cytometry in HIV/HCV co-infection, HIV mono-infection, HCV mono-infection, and healthy control group, as well as the dynamic changes of these cytokine levels after receiving highly active antiretroviral therapy (HAART).

Results: The ratio of Th1 and Th2 cytokine concentration in HIV/HCV co-infection was higher than HCV monoinfection and healthy control group, while lower than HIV mono-infection group. After HAART was initiated, the Th1/Th2 ratio of HIV/HCV co-infection group decreased to the same level of healthy control, while HIV monoinfection group was still higher than the control group.

Conclusions: There was no significant evidence showing co-infected with HCV had negative effect on HIV related diseases. However, co-infected with HCV can decrease Th1/Th2 ratio by affecting Th1 cytokine level, especially the secretion of IFN- $\gamma$. With the initiation of HAART, Th1 and Th2 cytokine levels were progressively reduced. HIV was the main stimulating factor of $\mathrm{T}$ cells in HIV/HCV co-infection group.

\section{Background}

Human immunodeficiency virus 1 (HIV-1) co-infected with hepatitis $\mathrm{C}$ virus (HCV) is very common because they share the same route of infection. These HIV/HCV co-infected persons account for approximately $25 \%$ of all HIV-infected persons all over the world [1]. Injection drug users (IDUs) are shown to be the highest risk factor of HIV/HCV co-infection [2-5]. According to a study investigation performed in 2008, approximately $63.2 \%$ of HIV-infected patients were co-infected with $\mathrm{HCV}$ in different areas of China [6], and the prevalence was $96.6 \%$ in IDUs and $92.9 \%$ in former paid blood donors (FBD) [7]. The previous studies indicated that

\footnotetext{
*Correspondence: kangwz@fmmu.edu.cn; yongtaos@hotmail.com † Contributed equally

Department of Infectious Diseases, Tangdu Hospital Affiliated to the Fourth Military Medical University, Xi'an, P.R. China
}

$\mathrm{HIV} / \mathrm{HCV}$ co-infection was associated with accelerated progression of liver disease and decreased survival rate among $\mathrm{HCV}$-infected individuals comparing with $\mathrm{HCV}$ mono-infection [8-10]. Since the widespread and effective introduction of highly active antiretroviral therapy (HAART) has successfully inhibited HIV-related diseases, the chronic liver diseases related to $\mathrm{HCV}$ have become one of the major causes of death in $\mathrm{HIV} / \mathrm{HCV}$ co-infected patients [11,12]. However, studies of the impact of HCV on HIV-infection have opposite conclusions. Some indicated HCV infection has a significant effect on the progression of HIV to AIDS defining illness and AIDS related mortality [13-16], while others found that HCV co-infection has no significant effect on HIV progression [17-22]. Neither of their mechanisms has been defined.

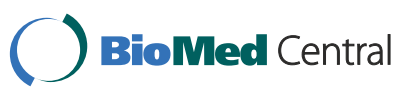

(c) 2012 Kang et al; licensee BioMed Central Ltd. This is an Open Access article distributed under the terms of the Creative Commons Attribution License (http://creativecommons.org/licenses/by/2.0), which permits unrestricted use, distribution, and reproduction in any medium, provided the original work is properly cited. 
Immunological impairment is the main characteristic of HIV pathogenesis. With the progressive loss of CD4 ${ }^{+}$ $\mathrm{T}$ cells in HIV infection, the dysfunction in the $\mathrm{T}$ cells compartment is reflected by cytokine expression levels [23-25]. In experimental models, it is widely accepted that susceptibility of BALB/c mice to L. major infection is associated with interleukin (IL)-4 and IL-10 produced by Th2 cells, whereas resistance is related to early and persistent interferon (IFN) $-\gamma$ produced by Th1 cells [26]. Simultaneous production of IFN- $\gamma$, tumor necrosis factor (TNF) $-\alpha$, and IL-10 by antigen-stimulated peripheral blood mononucleaer cells (PBMCs) from patients with active lesions [27] and IL-2, IL-4, IL-5, IL-10, and IFN- $\gamma$ mRNAs were demonstrated in biopsy samples taken from active lesions [28-30]. IL-10 expression was also significantly higher in patients who responded poorly to pentamidine treatment [28]. Many studies indicated that HIV-induced immunodeficiency often ascribed to a bias of Th1/Th2 balance towards Th2 cytokine responses [31], and this unbalance may recovered slightly when patients received antiretroviral therapy (ART). However, patients with weak immune response before treatment may retain deficiency of immune function, despite of successful inhibition of HIV viral load and increase CD4 ${ }^{+}$ $\mathrm{T}$ cell counts, including patients with impaired lymphoproliferative responses, antibody responses to vaccination and cutaneous delayed-type hypersensitivity responses [32]. In addition, HCV-induced liver diseases also affect Th1/Th2 orientation by increasing Th1-type cytokine production [33]. After stimulation by viral peptides or antigen, the Th1 and Th2 cytokine levels were reduced in mono-HIV infected women and more extensively in women with $\mathrm{HCV} / \mathrm{HIV}$ co-infection when compared with mono-HCV infection [34]. However, the expression profile of Th1/Th2 cytokine in HIV/HCV co-infected patients and their dynamic changes during HAART is rarely known.

In this study, we investigated the cytokine levels putatively produced by Th1 and Th2 cells in HIV/HCV coinfected, mono-HIV and mono-HCV infected patients as the antiviral treatment proceeding. Our prospection is to illustrate the difference of Th1/Th2 unbalance between $\mathrm{HIV} / \mathrm{HCV}$ co- and mono-infection by correlating the production of cytokines, which would be a convincible evidence of effect of HCV on HIV infected patients.

\section{Methods}

\section{Study participants}

A cohort including four groups in this study was established: HIV/HCV co-infected $(\mathrm{n}=20)$, HCV monoinfected $(\mathrm{n}=10)$, HIV mono-infected $(\mathrm{n}=20)$, and healthy controls $(n=10)$. For all participants, HCV infection was diagnosed according to the criteria as positive plasma $\mathrm{HCV}$ antibodies and detectable baseline $\mathrm{HCV}$
RNA (> 50 copies/ml); HIV infection was diagnosed according to the criteria as seropositive for HIV and nadir $\mathrm{CD}^{+}{ }^{+} \mathrm{T}$ cell counts with 350 cells/ $\mu$ l. Healthy control subjects were negative for both HCV and HIV antibodies. All study participants were recruited from the Department of Infectious Diseases of Tangdu Hospital (Xi'an, China) and the Guangzhou $8^{\text {th }}$ Hospital (Guangzhou, China). Neither the anti-HIV-positive nor anti$\mathrm{HCV}$-positive patients had received ART treatment. All studies were conducted with the approval of the ethical review board of each institution. The inform consent was get from each individual in this study.

\section{Antiretroviral therapy criteria}

$\mathrm{HIV} / \mathrm{HCV}$ co-infected patients started HAART treatment immediately after recruitment if their $\mathrm{CD} 4^{+} \mathrm{T}$ cell counts were $<200$ cells $/ \mu \mathrm{l}$. When the $\mathrm{CD} 4^{+} \mathrm{T}$ cell count was achieved at $>200$ cells $/ \mu$ l and kept stable within 3 months, anti-HCV ART (Peginterferon alfa-2a plus ribavirin) was initiated. If the $\mathrm{CD}^{+} \mathrm{T}$ cell counts were between 200 and 350 cells/ $\mu$ l, HAART was started first, anti-HCV ART was initiated after 12 weeks. HIV and HCV mono-infected patients started HAART and anti-HCV ART treatment directly after recruitment.

\section{Viral load and lymphocyte subsets test}

Both HIV and HCV plasma viral loads were analyzed by the immunofluorescence quantifying PCR assay (Roche Corporation, USA) according to the manufacturer's instructions. T-lymphocyte subsets were enumerated in 50 $\mu \mathrm{l}$ freshly obtained EDTA-anticoagulant whole blood using $20 \mu \mathrm{l}$ directly labeled mAbs (TriTEST: CD4-FIITC/ CD8-PE/CD3-PerCP) (BD Bioscience, USA) according to the "lyse-no-wash" procedure. All samples were acquired with a four-color FACS Calibur and analyzed using MultiSET software (Becton Dickison, USA).

\section{Th1 and Th2 cytokines test}

Six cytokines putatively produced by Th1 and Th2 cells, including IL-2, IL-4, IL-5, IL-10, TNF- $\alpha$ and IFN- $\gamma$, were detected using CBA Th1/Th2 cytokine kit (BD ${ }^{\text {TM }}$ Cytometric Bead Array, USA) according to the manufacturer's instruction. BD CellQuest software is required for acquiring samples and formatting data. Standard curves and sample cytokine concentration were calculated using the BD CBA Software (BD Bioscience, USA). Th1 cytokine levels were represented by the amount of concentrations of IFN- $\gamma$, IL- 2 and TNF- $\alpha$; Th2 cytokine levels were represented by the amount of concentrations of IL-4, IL-5 and IL-10.

\section{Statistical Analysis}

Data were expressed as the Median (interquartile range). Statistical analysis of demographics and laboratory 
parameters was performed by SPSS 13.0 using standard nonparametric statistical methods (Wilcoxon signedrank test and Mann-Whitney U test). Statistical analysis of cytokine concentration between groups was performed using GraphPad Prism version 5.00 for Windows (GraphPad Software, San Diego, CA) using the Bonferroni post-test. The differences of Th1/Th2 ratio between groups were compared using the Bonferroni's Multiple Comparison Test. Spearman correlation analysis was performed for correlation analysis. All tests were twotailed, and $p$ values of $<0.05$ indicated statistical significance.

\section{Results}

\section{Study population characteristics and antiretroviral} therapeutic situation

Four groups of patients were recruited into this study: HIV/HCV co-infected, HIV mono-infected, HCV monoinfected, and healthy controls. The demographics and laboratory parameters of the four groups are summarized in Table 1 . The mean age of HIV/HCV co-infections was older than HIV mono-infections $(p>0.05)$, as well as significantly younger than $\mathrm{HCV}$ mono-infections $(p<0.05)$. The main transmission route of HIV/HCV co-infected patients was IDU (80\%). The HIV mono-infections has the lowest nadir CD4 T cell count $(p<0.05)$ and highest HIV-1 RNA levels in plasma $(p<0.05)$ comparing with the other three study groups. The HCV RNA levels in plasma of HIV/HCV co-infection group were higher than $\mathrm{HCV}$ mono-infection group without statistical difference $(p>0.05)$.
All patients infected with HIV were treated with combined ART according to currently accepted guidelines (2NRTI + PI or 2NRTI + NNRTI). Patients infected with $\mathrm{HCV}$ were treated for 48 week with pegylated IFN alfa-2a $(180 \mu \mathrm{g} /$ week) and ribavirin (900 to $1,200 \mathrm{mg} /$ day, depending on body weight). HIV and HCV RNA levels were measured at six time points: before the start of therapy (baseline) and at 4, 12, 24, 36 and 48 weeks of antiretroviral therapy (Figure 1). HIV/HCV co-infected patients were more sensitive to HAART comparing with HIV mono-infected patients. However, after 48 weeks of HAART all patients had reached lower HIV-1 RNA level which could be considered as a great viral response to antiretroviral therapy (Figure 1A). HCV antiretroviral therapeutic situation indicated that $\mathrm{HIV} / \mathrm{HCV}$ coinfected patients were slower to reach sustained virologic response (SVR) than $\mathrm{HCV}$ mono-infected patients (Figure 1B).

\section{Th1 and Th2 cytokine concentration between four groups} at baseline

Six cytokines were detected using CBA Th1/Th2 cytokine kit, Th1/Th2 cytokine standard curves were shown in Figure 2. Cytokine concentration of plasma in patients was calculated according to the standard curves with $20 \mathrm{pg} / \mathrm{ml} \sim 5000 \mathrm{pg} / \mathrm{ml}$ quantifiable ranges. Results of six cytokines' concentration of plasma in four study groups were shown in Figure 3. IFN- $\gamma$ concentration was significantly lower in HIV/HCV co-infection group comparing with HIV mono-infection group $(p<0.001)$, while higher comparing with both HCV mono-infection $(p<0.001)$

Table 1 Baseline demographic and immunological parameters of study participants

\begin{tabular}{|c|c|c|c|c|}
\hline Parameters & $\begin{array}{l}\text { HIV/HCV } \\
\text { co-infection }\end{array}$ & $\begin{array}{l}\text { HIV } \\
\text { mono-infection }\end{array}$ & $\begin{array}{l}\text { HCV } \\
\text { mono-infection }\end{array}$ & Healthy control \\
\hline Number & 20 & 20 & 10 & 10 \\
\hline Sex ratio (male/female) & $13 / 7$ & $12 / 8$ & $7 / 3$ & $4 / 6$ \\
\hline Age (years) & $\begin{array}{l}39.00 \\
(35.25 \sim 41.50)^{c, d}\end{array}$ & $\begin{array}{l}37.00 \\
(32.75 \sim 41.50)^{c, d}\end{array}$ & $\begin{array}{l}45.50 \\
(39.50 \sim 48.50)^{a, b, d}\end{array}$ & $\begin{array}{l}26.50 \\
(25.00 \sim 29.25)^{a, b, c}\end{array}$ \\
\hline \multicolumn{5}{|l|}{$\begin{array}{l}\text { Transmission route } \\
(\text { no. }(\%))\end{array}$} \\
\hline Sex & $0(0)$ & $12(60)$ & $0(0)$ & - \\
\hline Blood & $4(20)$ & $1(5)$ & $10(100)$ & - \\
\hline IDU & $16(80)$ & $4(20)$ & $0(0)$ & - \\
\hline Unknown & $0(0)$ & $3(15)$ & $0(0)$ & - \\
\hline cD4 T cell count (cells/ $\mu$ l) & $\begin{array}{l}224.00 \\
(164.00 \sim 296.00) b, c, d\end{array}$ & $\begin{array}{l}131.00 \\
(73.75 \sim 194.50)^{a, c, d}\end{array}$ & $\begin{array}{l}522.50 \\
(448.00 \sim 599.00)^{a, b, d}\end{array}$ & $817.00(736.00 \sim 947.25)^{a, b, c}$ \\
\hline $\begin{array}{l}\text { HIV-1 Viral load } \\
\left(\log _{10} \text { copies/ml) }\right.\end{array}$ & $3.97(3.48 \sim 4.83)^{b}$ & $4.65(4.38 \sim 5.23)^{\mathrm{a}}$ & - & - \\
\hline $\begin{array}{l}\text { HCV Viral load } \\
\left(\log _{10} \text { copies/ml) }\right.\end{array}$ & $6.42(5.91 \sim 6.85)$ & - & $6.05(5.33 \sim 6.54)$ & - \\
\hline
\end{tabular}

a. $\mathrm{p}<0.05$ difference when compared to HIV/HCV co-infection

b. $\mathrm{p}<0.05$ difference when compared to HIV mono-infection

c. $p<0.05$ difference when compared to HCV mono-infection

d. $\mathrm{p}<0.05$ difference when compared to healthy control 


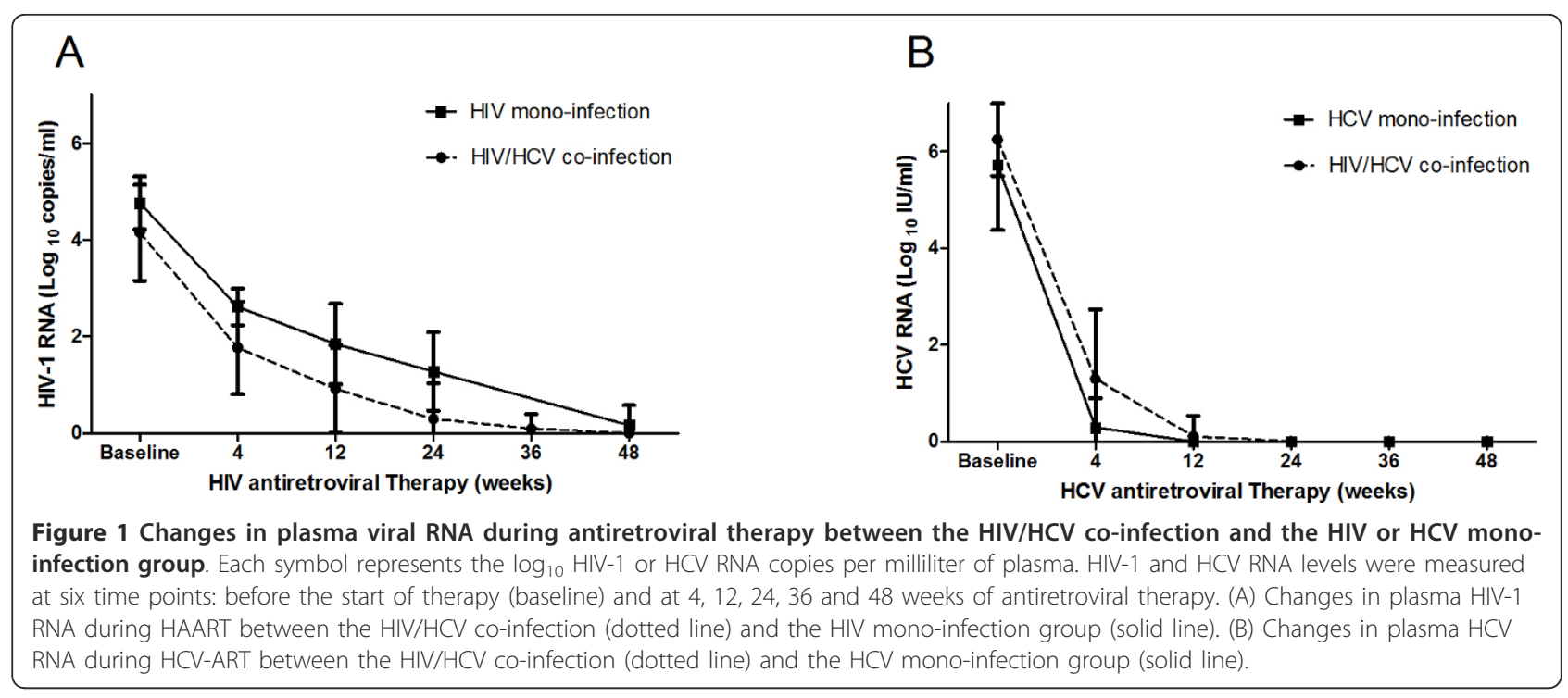

and healthy control group $(p<0.001)$. IL-10 concentration was highest in HIV/HCV co-infection group when compared with the other three groups, but it was only shown a statistical raise when compared with healthy control group $(p<0.01)$. In HIV/HCV co-infection group, IL-2 concentration was the highest without statistical difference $(p>0.05)$. Co-infection group and HIV mono-infection group revealed a slightly elevation of

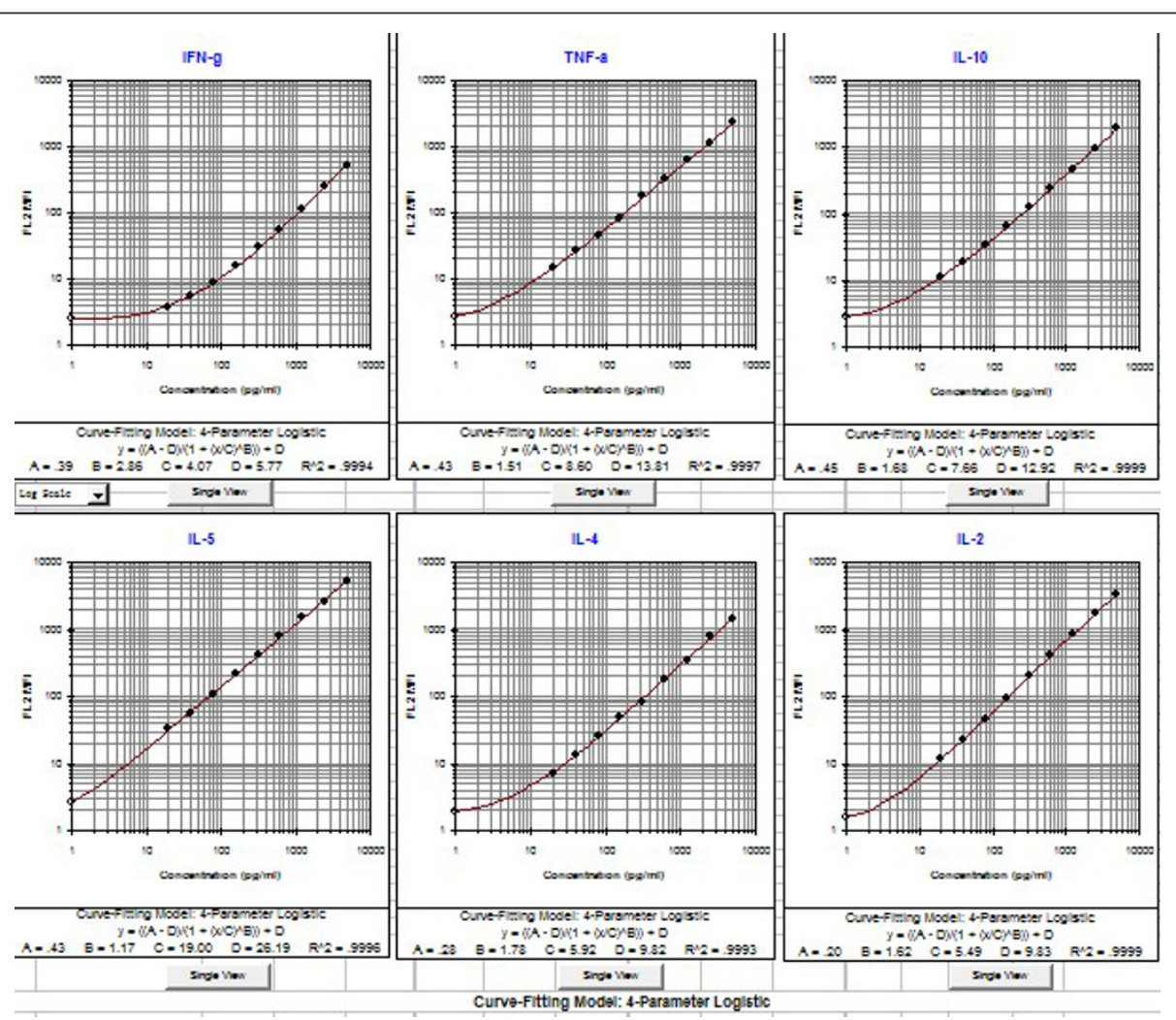

Figure 2 Th1/Th2 Cytokine Standard curves generated by BD CBA Software. Human Th1/Th2 Cytokine Standards were reconstituted in 2.0 $\mathrm{ml}$ of Assay Diluent; dilute the Standards primary liquid in a serial dilution rate as described: 1:2, 1:4, 1:8, 1:16, 1:32, 1:64, 1:128, and 1:256; prepare one tube containing Assay Diluent as negative control $(0 \mathrm{pg} / \mathrm{ml}) .50 \mu \mathrm{l}$ of the mixed Capture Beads, $50 \mu \mathrm{l}$ of the Human Th1/Th2 PE Detection Reagent, and $50 \mu \mathrm{l}$ of Cytokine Standard dilutions were mixed before acquiring by CellQuest software; standard curves were calculated using the BD CBA Software after acquiring, sample cytokine concentrations were calculated by standard curves. 


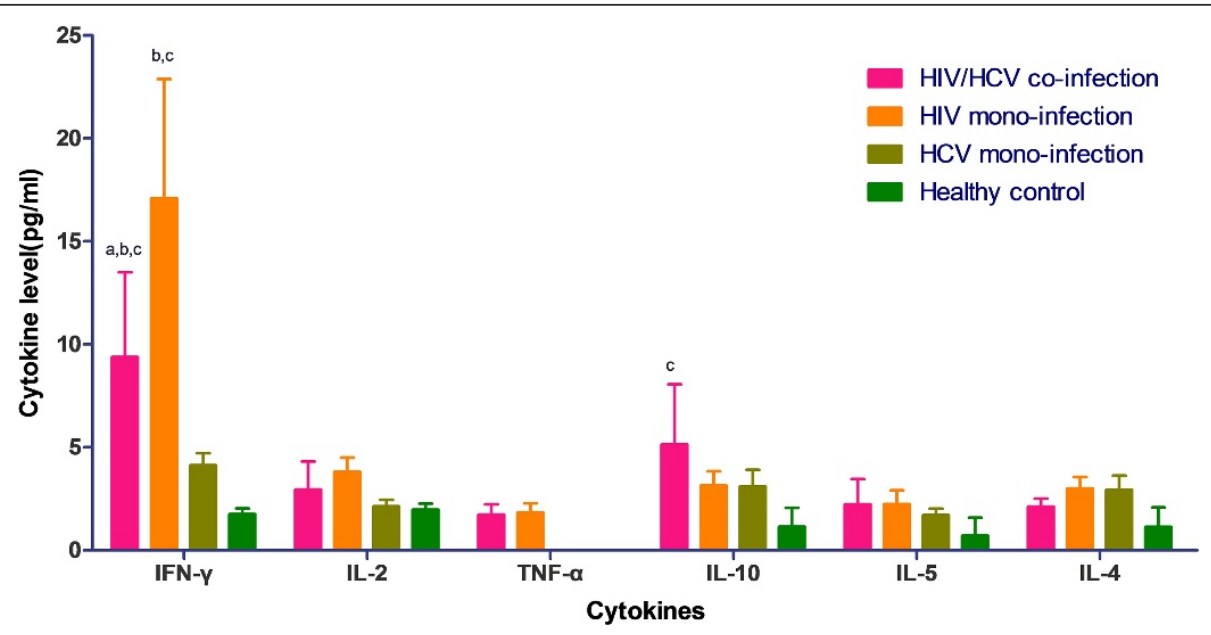

Figure 3 Comparison of Th1 and Th2 cytokine levels between different groups at baseline. Horizontal axis represents different kind of cytokines; vertical axis represents cytokine concentration $(\mathrm{pg} / \mathrm{ml})$ in plasma. Four coloured bar represents different study groups: HIV/HCV coinfection group (pink bars), HIV mono-infection group (orange bars), HCV mono-infection group (olive bars), and healthy control (green bars).

IL-5 concentration when compared with HCV monoinfection and healthy control group $(p>0.05)$, while the same level between HIV mono-infection. TNF- $\alpha$ concentration was detectable in the people who were infected with HIV. Co-infection group has lower IL-4 concentration compared with both HIV mono- and HCV monoinfection group, while higher than healthy control group.

Furthermore, we estimated the ratio of Th1 and Th2 by calculating Th1/2 cytokines' concentration, thus to evaluate the change of Th1/Th2 expression balance. The ratio of Th1 and Th2 cytokine concentration was presented in Figure 4, illustrating the HIV mono-infection group had the highest ratio than the others $(p<0.001)$; the ratio of $\mathrm{HIV} / \mathrm{HCV}$ co-infection group was significantly lower than HIV mono-infection group $(p<0.001)$ and higher than HCV mono-infection $(p<0.05)$. Comparing with healthy controls, infected with HIV could induce higher Th1 cytokine levels, however, infected with HCV could induce higher Th2 cytokine level. Considering these two opposite effects, we observed a coordinative result in the HIV/HCV co-infection group, which was higher than HCV monoinfection and lower than HIV mono-infection group.

\section{Dynamic changes of Th1 and Th2 cytokines during HAART}

After initiating HAART, we estimated Th1 and Th2 cytokine levels of the HIV mono-infection and the HIV/HCV co-infection group at series time-points (baseline, 4 weeks, 12 weeks, 24 weeks and 48 weeks). Concentration of IFN$\gamma$ at 48 weeks after HAART in HIV/HCV co-infected patients indicated a significant decrease comparing with the other time points $(p<0.01)$ (Figure $5 \mathrm{~A}$ ), while the other cytokine levels presented no statistical differences. However, concentration of IFN- $\gamma$ in HIV mono-infection group was more variable during HAART (Figure 5B). IFN$\gamma$ was secreted at the highest level at the baseline $(p<$ $0.001)$, fell sharply at 4 weeks after HAART $(p<0.05)$, rebounded at 24 weeks $(p<0.001)$, and fell down again at 48 weeks $(p<0.001)$. Concentrations of IL-2 shown peak

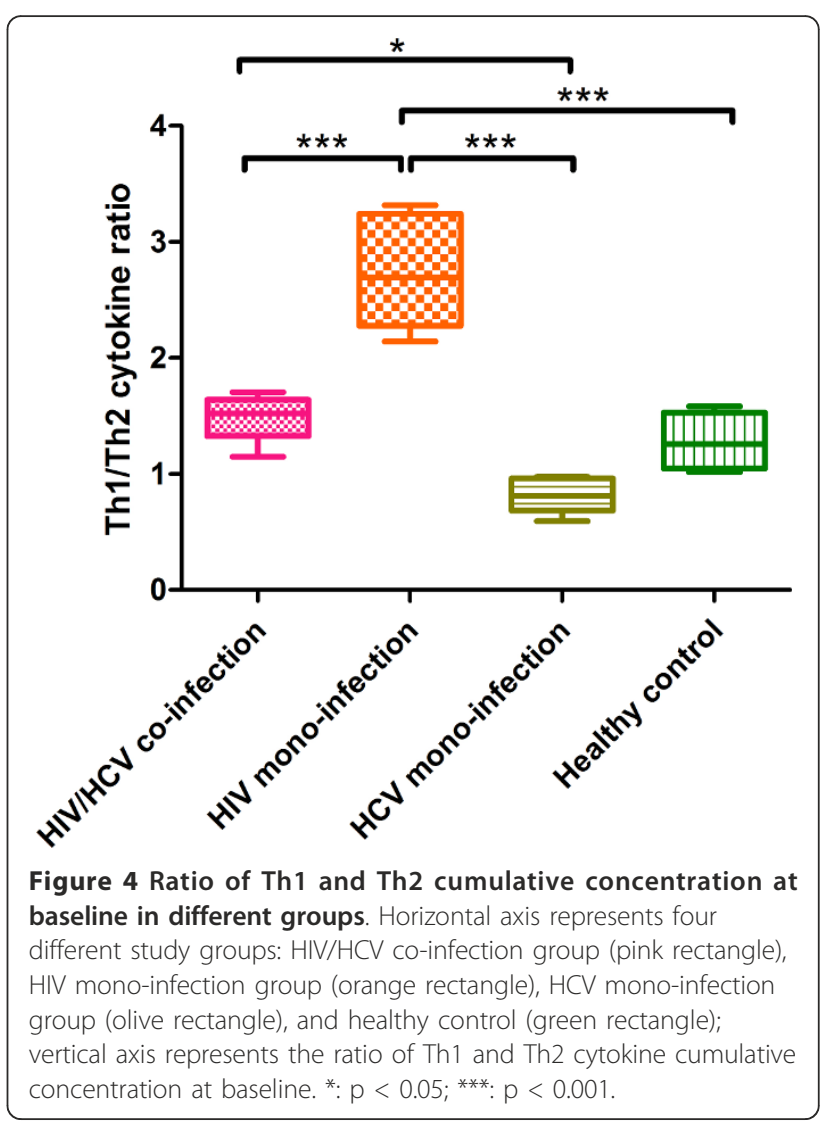



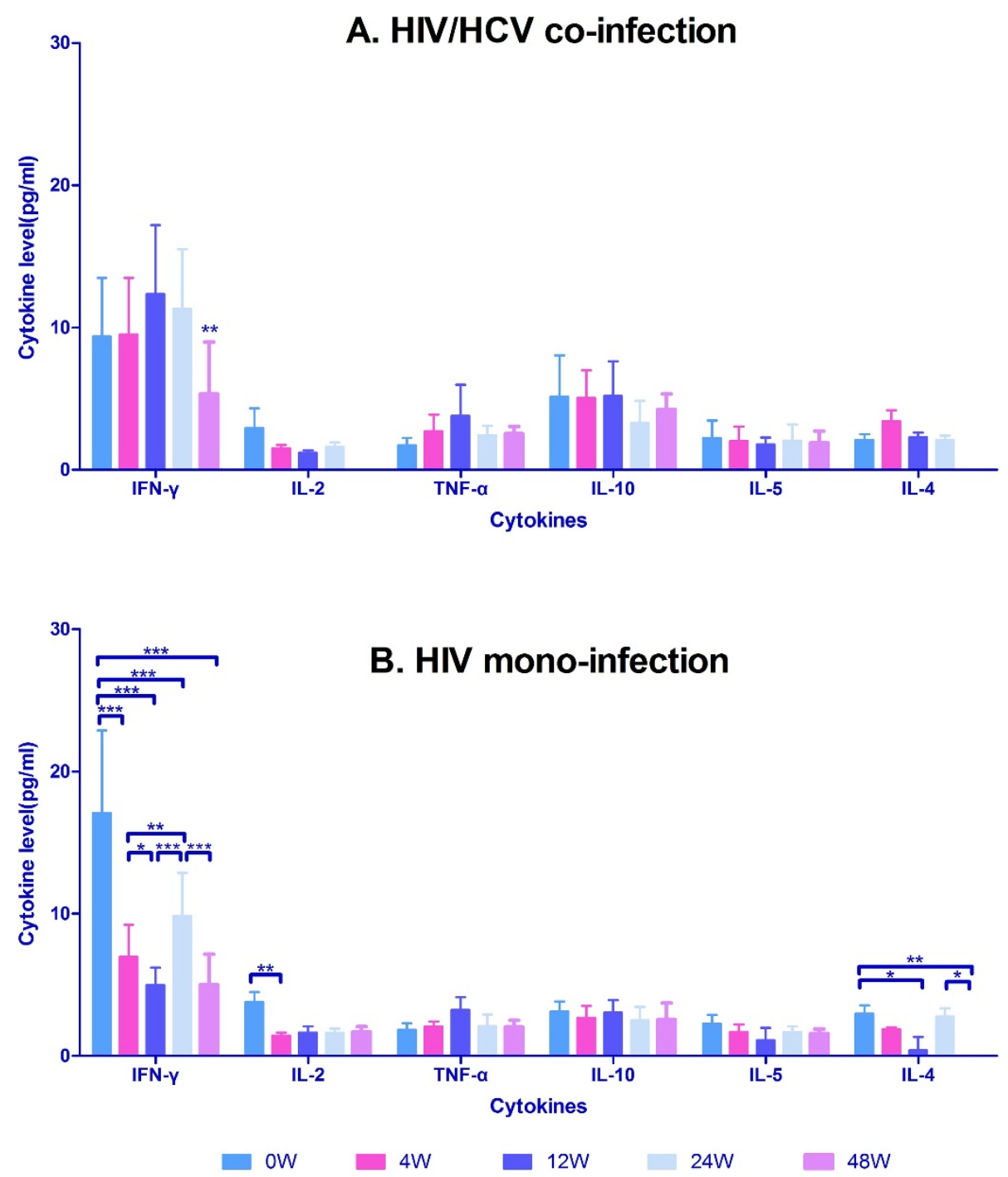

Figure 5 Comparison of Th1 and Th2 cytokine concentration during HAART between HIV/HCV co-infection and HIV mono-infection group. Horizontal axis represents six time points with different colour bars: before the start of therapy ( 0 W, Paris blue bars) and at 4 (pink bars), 12(blue bars), 24 (light blue bars), and 48 weeks (lavender bars) of HAART; vertical axis represents cytokine concentration (pg/ml) in plasma. (A) Dynamic change of Th1 and Th2 cytokine concentration during HAART in HIV/HCV co-infection group; (B) Dynamic change of Th1and Th2 cytokine concentration during HAART in HIV mono-infection group. $*$ : $<<0.05$; ${ }^{*}: p<0.01 ;{ }^{* *}: p<0.001$.

level at baseline, descended quickly at 4 weeks $(p<0.01)$, and ascended slightly as time-varying $(p>0.05)$. IL-4 was secreted at first $(p<0.05)$, descended progressively after HAART in 12 weeks $(p<0.05)$, rebounded abruptly at 24 weeks $(p>0.05)$, and fell off at 48 weeks $(p<0.05)$. TNF$\alpha$, IL-10 and IL-5 levels remained the same level of baseline as HAART was proceeding.

The change of Th1/Th2 ratio of mono- and co-infection group was demonstrated in Figure 6, which indicated that co-infection group has a complete different pattern during HAART; Th1/Th2 ratio in co-infection group was stabilized at first then elevated at 12 weeks, and descended after 12 weeks; while in HIV mono-infection group Th1/ Th2 ratio fell sharply in 4 weeks then kept stable after with a slightly ascending trend. After 48 weeks treatment of HAART, Th1/Th2 ratio of HIV/HCV co-infected patients stayed in the same level of healthy control group. However, HIV mono-infection group was still higher than the control group.

Furthermore, we evaluated the changes of Th1 and Th2 cytokine levels of the entire HIV infected patients who had received HAART. There was an obviously time-varying descending pathway (Figure 7). Th1 cytokine levels seemed more sensitive to HAART than Th2. 


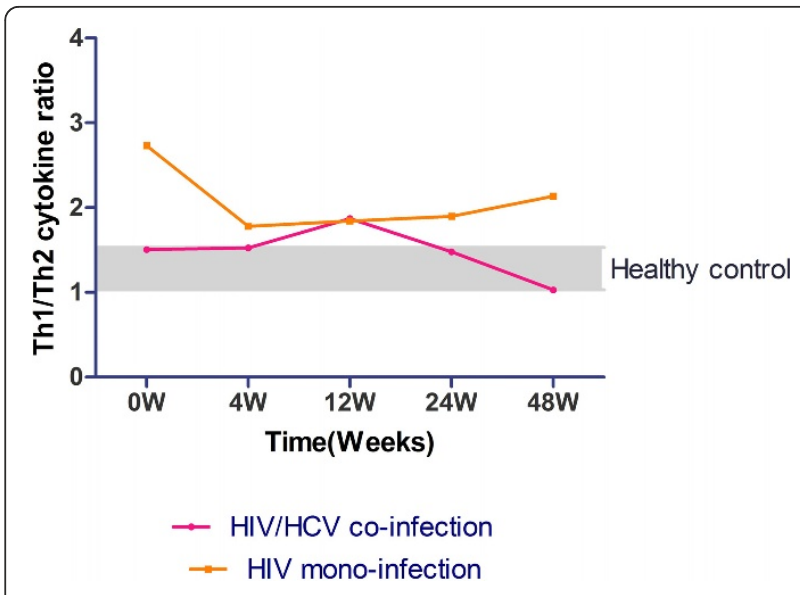

Figure 6 Comparison of the dynamic change of Th1/Th2 cytokine ratio during HAART between HIV/HCV co-infection group and HIV mono-infection group. Vertical axis represents the ratio of Th1 and Th2 cytokine cumulative concentration at baseline; two coloured lines represent different study group: HIV/HCV coinfection group (pink line), HIV mono-infection group (orange line). Gray zone was shown as the Th1/Th2 ratio range of healthy control.

Relationships between Th1/Th2 cytokines, CD4+ T lymphocyte count and virus load

We analyzed the correlations between the main factors concerned, included $\mathrm{CD} 4^{+} \mathrm{T}$ lymphocyte count, HIV viral load, concentration of Th1 and Th2 cytokines (IL-2, IL-4, IL-5, IL-10, TNF- $\alpha$ and IFN- $\gamma$ ) and Th1/Th2 ratio, the results were exhibited on Table 2 . Statistic results indicated that HIV-1 viral load had strong positive correlation with most Th1 and Th2 cytokine levels, especially in IFN$\gamma(\mathrm{r}=0.537 ; p<0.01)$, IL-2 $(\mathrm{r}=0.592 ; p<0.01), \mathrm{IL}-10(\mathrm{r}=$

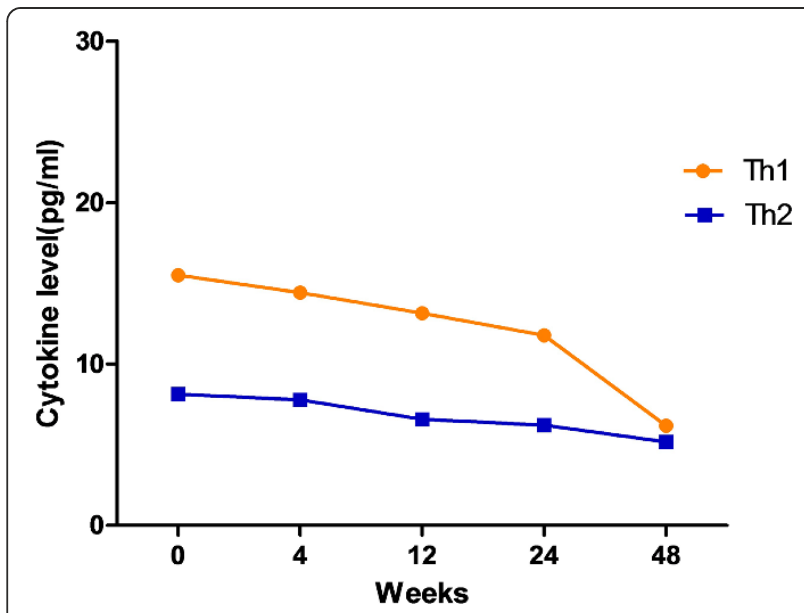

Figure 7 Changes of Th1 and Th2 cytokine expression levels during HAART in both HIV mono-infection and HIV/HCV coinfection group. Vertical axis represents cytokine concentration $(\mathrm{pg} / \mathrm{ml})$ in plasma. The orange line represents Th1 cytokine cumulative concentration $(\mathrm{pg} / \mathrm{ml})$; the blue line represents Th2 cytokine cumulative concentration (pg/ml).
$0.381 ; p<0.01)$ and IL-5 ( $\mathrm{r}=0.360 ; p<0.01)$, while negative correlation with TNF- $\alpha(\mathrm{r}=-0.405 ; p<0.05) . \mathrm{CD}^{+} \mathrm{T}$ lymphocyte count had significant negative correlation with HIV viral load ( $\mathrm{r}=-0.519 ; p<0.01)$, IL-2 ( $\mathrm{r}=-0.335 ; p<$ $0.01)$ and IL-5 ( $\mathrm{r}=-0.317 ; p<0.01)$ concentration, and Th1/Th2 ratio $(r=-0.236 ; p<0.05)$. IFN- $\gamma$, IL-2, IL-10, Th1 cytokines levels and Th2 cytokines levels all had strong positive correlations with the cytokine concentration except TNF- $\alpha$. Moreover, TNF- $\alpha$ was the most insensitive immune cytokine which did not correlated with the others except a negative correlation with HIV viral load $(\mathrm{r}=-0.405 ; p<0.05)$. As the proceeding of HAART, HIV viral load was inhibited, $C D 4^{+} \mathrm{T}$ lymphocyte count aroused, TNF- $\alpha$ expression raised, the concentration of IFN- $\gamma$, IL- 2 , IL-5 and IL-10 progressively decreased. However, Th1 cytokine behaved more sensitive than Th2 cytokine under the effect of HAART. IFN- $\gamma$ secretion had a strong and intense relationship with Th1 cytokine levels $(\mathrm{r}=0.969 ; p<0.01)$, which indicated that IFN- $\gamma$ might play an important role in Th1/Th2 balance.

\section{Discussion}

Although HIV co-infection clearly accelerates progression of HCV-related fibrosis and liver disease [35-38], the role of $\mathrm{HCV}$ in HIV disease progression remains controversial. HIV and HCV are intracellular parasites, therefore $\mathrm{T}$-cell responses are crucial for antiviral defense and cytotoxic T lymphocyte (CTL) play a principal task by destructing infected cells $[39,40]$. Moreover, viral gene expression can be suppressed by the antiviral cytokines. Thus, both of the quantity and quality of $\mathrm{T}$ cells are essential on disease pathology [41]. Cytokines derived from CD4+ $\mathrm{T}$ cells play a prominent role in viral infection, fostering elimination of intracellular pathogen and promoting host viral responses including CTL generation and natural killer cell activation (Th1), or driving humoral immune responses and inhibit the development of Th1 responses (Th2) [42]. Therefore, it seems to be a delicate balance between the beneficial and detrimental effects of HCV co-infection on the HIV related disease progression and therapeutic results which require further study.

To investigate the imbalance of Th1 and Th2 cytokines in the peripheral blood of patients with HIV and/or HCV infection, we evaluated the cytokine levels by using flow cytometry in plasma, as well as the dynamic changes of cytokine concentrations during HAART. We found that HIV/HCV co-infected group had statistically higher CD4 + T lymphocyte count, lower HIV viral load, and older mean age than HIV mono-infected patients. This fact may be an indirect evidence to support that co-infection with $\mathrm{HCV}$ has no effect on the progression of HIV to AIDS. We also found a higher detection level of HCV RNA in the HCV/HIV co-infected group compared to 
Table 2 Correlation between the concentration of Th1/Th2 cytokines, CD4 ${ }^{+} \mathrm{T}$ lymphocyte count, virus load and Th1/ Th2 cytokine ratio

\begin{tabular}{|c|c|c|c|c|c|c|c|c|c|c|c|}
\hline Correlation Coefficient & CD4 & VL & IFN- $\gamma$ & TNF- $\alpha$ & IL-2 & Th1 cytokines & IL-10 & IL-5 & IL-4 & Th2 cytokines & Th1/Th2 ratio \\
\hline$\overline{C D 4}$ & 1.000 & $-0.519^{a}$ & -0.192 & 0.262 & $-0.335^{a}$ & -0.112 & -0.019 & $-0.317^{a}$ & 0.108 & 0.121 & $-0.236^{b}$ \\
\hline$V L$ & $-0.519^{a}$ & 1.000 & $0.537^{\mathrm{a}}$ & $-0.405^{b}$ & $0.592^{a}$ & $0.534^{a}$ & $0.381^{a}$ & $0.360^{a}$ & 0.112 & $0.295^{b}$ & $0.383^{\mathrm{a}}$ \\
\hline IFN- $\gamma$ & -0.192 & $0.537^{\mathrm{a}}$ & 1.000 & -0.229 & $0.443^{\mathrm{a}}$ & $0.969^{\mathrm{a}}$ & $0.286^{\mathrm{b}}$ & $0.315^{\mathrm{a}}$ & $0.383^{\mathrm{a}}$ & $0.498^{\mathrm{a}}$ & $0.701^{\mathrm{a}}$ \\
\hline TNF- $\alpha$ & 0.262 & $-0.405^{b}$ & -0.229 & 1.000 & -0.257 & -0.092 & 0.043 & -0.115 & 0.157 & 0.117 & -0.214 \\
\hline IL-2 & $-0.335^{a}$ & $0.592^{a}$ & $0.443^{\mathrm{a}}$ & -0.257 & 1.000 & $0.407^{\mathrm{a}}$ & $0.510^{\mathrm{a}}$ & $0.430^{\mathrm{a}}$ & $0.298^{\mathrm{b}}$ & $0.334^{a}$ & $0.287^{b}$ \\
\hline $\begin{array}{l}\text { Th1 } \\
\text { cytokines }\end{array}$ & -0.112 & $0.534^{a}$ & $0.969^{a}$ & -0.092 & $0.407^{a}$ & 1.000 & $0.270^{b}$ & $0.278^{b}$ & $0.329^{b}$ & $0.486^{\mathrm{a}}$ & $0.775^{a}$ \\
\hline IL-10 & -0.019 & $0.381^{a}$ & $0.286^{b}$ & 0.043 & $0.510^{a}$ & $0.270^{b}$ & 1.000 & $0.362^{a}$ & $0.290^{b}$ & $0.690^{a}$ & -0.155 \\
\hline$\overline{I L-5}$ & $-0.317^{\mathrm{a}}$ & $0.360^{a}$ & $0.315^{a}$ & -0.115 & $0.430^{\mathrm{a}}$ & $0.278^{b}$ & $0.362^{a}$ & 1.000 & 0.233 & $0.433^{a}$ & 0.139 \\
\hline IL-4 & 0.108 & 0.112 & $0.383^{\mathrm{a}}$ & 0.157 & $0.298^{b}$ & $0.329^{b}$ & $0.290^{b}$ & 0.233 & 1.000 & $0.668^{\mathrm{a}}$ & -0.009 \\
\hline $\begin{array}{l}\text { Th2 } \\
\text { cytokines }\end{array}$ & 0.121 & $0.295^{b}$ & $0.498^{a}$ & 0.117 & $0.334^{a}$ & $0.486^{a}$ & $0.690^{a}$ & $0.433^{\mathrm{a}}$ & $0.668^{a}$ & 1.000 & -0.104 \\
\hline
\end{tabular}

Each data represents the correlation coefficient betwwen horizontal and vertical effectors which are overlapped.

a. Correlation is significant at the 0.01 level (2-tailed)

b. Correlation is significant at the 0.05 level (2-tailed)

the HCV mono-infected group; these findings are consistent with other studies [43]. At the baseline level, coinfected with HCV can decrease the cytokine levels produced by both Th1 and Th2 cells comparing with HIV mono-infection except IL-10; HIV mono-infection had the highest Th1 immune responses by secreting IFN- $\gamma$ compared with other groups; Th2 cytokine levels were lower than Th1, demonstrated a profile dominated by Th1 cytokines before HAART. HIV or HCV mono-infection with higher Th1 cytokine expressions may account for a milder course of liver disease in HCV mono-infection $[33,44]$; Th1 to Th2 switch led to the contraction of AIDS [45]. Therefore, we suggested that co-infection with HIV didn't worsen liver diseases by the performance of cytokine levels.

HIV infection specifically depressed CD4+ T cell and kept viral replication at high levels, which ultimately led to AIDS syndromes. On the other hand, many studies found that infected with HIV could cause cytokine expression of Th1 to Th2 during progresses of AIDS. By analyzing the former factors related with diseases progression. We found that HIV/HCV co-infection group had lower Th1/Th2 ratio, the $\mathrm{CD}^{+} \mathrm{T}$ lymphocyte count and HIV viral load was higher than HIV mono-infected group. Therefore, we reached a conclusion that there's no sufficient corroboration for that co-infected with HCV has negative effect on HIV related diseases. As we mentioned before, the influence of HCV on HIV infected patients was probably in the functional disorder of the $\mathrm{T}$ cells, which can not be determined by the quantity of cytokine levels. Infected with different viruses could lead to different characteristic performances of Th1/Th2 imbalance. Contrasting with the healthy control, the cytokine levels were dominated by Th1 cytokines in HIV mono-infection group, while in $\mathrm{HCV}$ mono-infection the advantage of Th1 was replaced by Th2 cytokines, thus for co-infection group Th1/Th2 balance was medium between the two mono-infections. These findings were similar to the study of P. Price et al. [34], which indicated that compared with single infected patients, the $\mathrm{T}$ helper response of co-infected with HIV and $\mathrm{HCV}$ was markedly reduced. Thus, co-infected with HCV could cause a lower Th1/Th2 ratio by decreasing Th1 cytokine expressions, especially in the IFN- $\gamma$ level. $\mathrm{HIV} / \mathrm{HCV}$ co-infection and HIV mono-infection group presented differently after HAART. As HAART successfully inhibited HIV replication and elevated $\mathrm{CD} 4^{+} \mathrm{T}$ lymphocytes, the reactivity of Th1 and Th2 cells was changed evidently from baseline. Co-infected with $\mathrm{HCV}$ seemed to play a role in deregulating both Th1 and Th2 cytokine expressions. Th1/Th2 balances in different study groups during HAART were also performing in two different ways, which implied co-infected with HCV affected mostly on Th1 cytokine expressions leading to a progressive decrease. The strong and positive correlation between HIV viral load and Th1 and Th2 cytokine levels indicated that HIV was an essential influencing factor on the reactivity of Th1 and Th2 cells. Therefore, Th1 and Th2 cytokine levels were reduced as HAART proceeding. As there's no significant correlation between $\mathrm{CD} 4^{+} \mathrm{T}$ lymphocyte count and Th1 and Th2 cytokine levels, we proposed the possible reason for increasing cytokine expression was the HIV itself. It was the stimulation of the HIV protein on T cells that caused the high cytokine expressions, which needed further study to reveal the molecular mechanism of this effect.

\section{Conclusions}

In summary, this study investigated the differences of Th1 and Th2 cytokine levels between HIV/HCV co- 
infection and HIV or HCV mono-infection group as well as the change of Th1/Th2 balance during HAART. There was no significant evidence that co-infected with $\mathrm{HCV}$ had any negative effects on HIV related diseases. However, co-infected with HCV can decrease Th1/Th2 ratio by affecting Th1 cytokine expression. With initiating of HAART, Th1 and Th2 cytokine levels were progressively reduced. HIV was the main stimulation factor of $\mathrm{T}$ cells in co-infection. Additional studies are needed to illustrate the mechanism behind reduced HCV-specific $\mathrm{T}$ helper responses, as well as the clinical implications of reduced cytokine responses in co-infected patients.

\section{Acknowledgements}

We thank all the subjects who agreed to participate in this study. We are also grateful to researchers of $8^{\text {th }}$ hospital of Guangzhou for their great help and cooperation. This work is supported by Two Grand Programs on Key Infectious Disease 2012ZX10001003-003 and 2008ZX10001-002 projects.

\section{Authors' contributions}

YZ recruited the subjects and collected the samples. $\mathrm{KZ}, \mathrm{DH}$ performed the CD4 cell count and viral load tests. YL, YZ carried out the test of Th1 and Th2 cytokines. WK, YL, YZ, DH carried out the data analysis and drafted the manuscript. WK, YS conceived of the study, and participated in its design and coordination. All authors read and approved the final manuscript.

\section{Competing interests}

The authors declare that they have no competing interests.

Received: 30 August 2011 Accepted: 25 April 2012

Published: 25 April 2012

\section{References}

1. Sherman K, Rouster S, Chung R, Rajicic N: Hepatitis C virus prevalence among patients infected with human immunodeficiency virus: a crosssectional analysis of the US adult AIDS Clinical Trials Group. Clin Infect Dis 2002, 34:831-837.

2. Mayor AM, Gomez MA, Fernandez DM, Rios-Olivares E, Thomas JC, Hunter RF: Morbidity and mortality profile of human immunodeficiency virus-infected patients with and without hepatitis C co-infection. Am J Trop Med Hyg 2006, 74:239-245.

3. Solomon SS, Srikrishnan AK, Mehta SH, Vasudevan CK, Murugavel KG, Thamburaj E, Anand S, Kumar MS, Latkin C, Solomon S, Celentano DD: High prevalence of HIV, HIV/hepatitis C virus coinfection, and risk behaviors among injection drug users in Chennai, India: a cause for concern. J Acquir Immune Defic Syndr 2008, 49:327-332.

4. Zhang C, Yang R, Xia X, Qin S, Dai J, Zhang Z, Peng Z, Wei T, Liu H, Pu D, et al: High prevalence of HIV-1 and hepatitis C virus coinfection among injection drug users in the southeastern region of Yunnan, China. $J$ Acquir Immune Defic Syndr 2002, 29:191-196.

5. Xia X, Luo J, Bai J, Yu R: Epidemiology of hepatitis C virus infection among injection drug users in China: Systematic review and metaanalysis. Public Health 2008, 122:990-1003.

6. Zhang M, Hu Q-h, Zhao F, et al: Investigation of HIV co-infection with hepatitis $C$ virus through different infectious routes. Chin J Public Health 2008, 24:1409-1411.

7. Shang H, Zhong P, Liu J, Han X, Dai D, Zhang M, Zhao K, Xu R, Yu X-F: High Prevalence and Genetic Diversity of HCV among HIV-1 Infected People from Various High-Risk Groups in China. PLoS One 2010, 5:e10631.

8. Mohsen AH, Easterbrook P, Taylor CB, Norris S: Hepatitis C and HIV-1 coinfection. Gut 2002, 51:601-608

9. Graham CS, Baden LR, Yu E, Mrus JM, Carnie J, Heeren T, Koziel MJ: Influence of human immunodeficiency virus infection on the course of hepatitis C virus infection: a meta-analysis. Clin Infect Dis 2001, 33:562-569.
10. Shepard CW, Finelli L, Alter MJ: Global epidemiology of hepatitis C virus infection. Lancet Infect Dis 2005, 5:558-567.

11. Dodig M, Tavill AS: Hepatitis $C$ and human immunodeficiency virus coinfections. J Clin Gastroenterol 2001, 33:367-374.

12. Mohsen AH, Easterbrook PJ, Taylor C, Portmann B, Kulasegaram R, Murad S, Wiselka M, Norris S: Impact of human immunodeficiency virus (HIV) infection on the progression of liver fibrosis in hepatitis $\mathrm{C}$ virus infected patients. Gut 2003, 52:1035-1040.

13. Greub G, Ledergerber B, Battegay M, Grob P, Perrin L, Furrer $H$, Burgisser $P$, Erb P, Boggian K, Piffaretti JC, et al: Clinical progression, survival, and immune recovery during antiretroviral therapy in patients with HIV-1 and hepatitis C virus coinfection: the Swiss HIV Cohort Study. Lancet 2000, 356:1800-1805.

14. Lesens O, Deschenes M, Steben M, Belanger G, Tsoukas C: Hepatitis C virus is related to progressive liver disease in human immunodeficiency viruspositive hemophiliacs and should be treated as an opportunistic infection. J Infect Dis 1999, 179:1254-1258.

15. Daar ES, Lynn H, Donfield S, Gomperts E, O'Brien SJ, Hilgartner MW, Hoots WK, Chernoff D, Arkin S, Wong WY, Winkler CA: Hepatitis C virus load is associated with human immunodeficiency virus type 1 disease progression in hemophiliacs. J Infect Dis 2001, 183:589-595.

16. Piroth L, Duong M, Quantin C, Abrahamowicz M, Michardiere R, Aho LS, Grappin M, Buisson M, Waldner A, Portier H, Chavanet P: Does hepatitis C virus co-infection accelerate clinical and immunological evolution of HIV-infected patients? AIDS 1998, 12:381-388

17. Staples CT Jr, Rimland D, Dudas D: Hepatitis $C$ in the HIV (human immunodeficiency virus) Atlanta V.A. (Veterans Affairs Medical Center) Cohort Study (HAVACS): the effect of coinfection on survival. Clin Infect Dis 1999, 29:150-154

18. Dorrucci M, Pezzotti P, Phillips A, Cozzi Lepri A, Rezza G: Coinfection of hepatitis $C$ virus with human immunodeficiency virus and progression to AIDS. J Infect Dis 1995, 172:1503-1508.

19. Rockstroh JK, Mocroft A, Soriano V, Tural C, Losso MH, Horban A, Kirk O, Phillips A, Ledergerber B, Lundgren J: Influence of hepatitis C virus infection on HIV-1 disease progression and response to highly active antiretroviral therapy. J Infect Dis 2005, 192:992-1002.

20. Sulkowski MS, Moore RD, Mehta SH, Chaisson RE, Thomas DL: Hepatitis C and progression of HIV disease. JAMA 2002, 288:199-206.

21. Bonacini M, Louie S, Bzowej N, Wohl AR: Survival in patients with HIV infection and viral hepatitis B or C: a cohort study. AIDS 2004, 18:2039-2045.

22. Lincoln D, Petoumenos K, Dore GJ: HIV/HBV and HIV/HCV coinfection, and outcomes following highly active antiretroviral therapy. HIV Med 2003, 4:241-249

23. Clerici M, Hakim FT, Venzon DJ, Blatt S, Hendrix CW, Wynn TA, Shearer GM: Changes in interleukin-2 and interleukin-4 production in asymptomatic, human immunodeficiency virus-seropositive individuals. J Clin Invest 1993, 91:759-765.

24. Fan J, Bass HZ, Fahey JL: Elevated IFN-gamma and decreased IL-2 gene expression are associated with HIV infection. J Immunol 1993, 151:5031-5040

25. Graziosi C, Gantt KR, Vaccarezza M, Demarest JF, Daucher M, Saag MS, Shaw GM, Quinn TC, Cohen OJ, Welbon CC, et al: Kinetics of cytokine expression during primary human immunodeficiency virus type 1 infection. Proc Natl Acad Sci USA 1996, 93:4386-4391.

26. Sacks D, Noben-Trauth N: The immunology of susceptibility and resistance to Leishmania major in mice. Nat Rev Immunol 2002, 2:845-858.

27. Trujillo CM, Robledo SM, Franco IL, Velez ID, Erb KJ, Patino PJ: Endemically exposed asymptomatic individuals show no increase in the specific Leishmania (Viannia) panamensis-Th1 immune response in comparison to patients with localized cutaneous leishmaniasis. Parasite Immunol 2002, 24:455-462.

28. Bourreau E, Prevot G, Gardon J, Pradinaud R, Launois P: High intralesional interleukin-10 messenger RNA expression in localized cutaneous leishmaniasis is associated with unresponsiveness to treatment. J Infect Dis 2001, 184:1628-1630.

29. Louzir H, Melby PC, Ben Salah A, Marrakchi H, Aoun K, Ben Ismail R, Dellagi K: Immunologic determinants of disease evolution in localized cutaneous leishmaniasis due to Leishmania major. J Infect Dis 1998, 177:1687-1695. 
30. Pirmez C, Yamamura M, Uyemura K, Paes-Oliveira M, Conceicao-Silva F, Modlin RL: Cytokine patterns in the pathogenesis of human leishmaniasis. J Clin Invest 1993, 91:1390-1395.

31. Del Prete G, Maggi E, Pizzolo G, Romagnani S: CD30, Th2 cytokines and HIV infections: a complex and fascinating link. Immunol Today 1995, 16:76-80.

32. Lederman H, Williams P, Wu J, Evans T, Cohn S, McCutchan J, Koletar S, Hafner R, Connick E, Valentine F: Incomplete Immune Reconstitution after Initiation of Highly Active Antiretroviral Therapy in Human Immunodeficiency Virus-Infected Patients with Severe CD4 Cell Depletion. J Infect Dis 2003, 188:1794-1803.

33. Loffreda S, Muratori P, Muratori L, Mele L, Bianchi FB, Lenzi M: Enhanced monocyte Th1 cytokine production in HCV-infected cryoglobulinemic patients. J Hepatol 2003, 38:230-236.

34. Villacres MC, Literat O, Degiacomo M, Du W, La Rosa C, Diamond DJ, Kovacs A: Reduced type 1 and type 2 cytokines in antiviral memory $T$ helper function among women coinfected with HIV and HCV. J Clin Immunol 2005, 25:134-141.

35. Darby SC, Ewart DW, Giangrande PL, Spooner RJ, Rizza CR, Dusheiko GM, Lee CA, Ludlam CA, Preston FE: Mortality from liver cancer and liver disease in haemophilic men and boys in UK given blood products contaminated with hepatitis C. UK Haemophilia Centre Directors' Organisation. Lancet 1997, 350:1425-1431.

36. Soto B, Sanchez-Quijano A, Rodrigo L, del Olmo JA, Garcia-Bengoechea M, Hernandez-Quero J, Rey C, Abad MA, Rodriguez M, Sales Gilabert M, et al: Human immunodeficiency virus infection modifies the natural history of chronic parenterally-acquired hepatitis $C$ with an unusually rapid progression to cirrhosis. J Hepatol 1997, 26:1-5.

37. Lin W, Wu G, Li S, Weinberg EM, Kumthip K, Peng LF, Mendez-Navarro J, Chen WC, Jilg N, Zhao H, et al: HIV and HCV cooperatively promote hepatic fibrogenesis via induction of reactive oxygen species and NFkappaB. J Biol Chem 2011, 286:2665-2674.

38. Tuyama AC, Hong F, Saiman Y, Wang C, Ozkok D, Mosoian A, Chen P, Chen BK, Klotman ME, Bansal MB: Human immunodeficiency virus (HIV)-1 infects human hepatic stellate cells and promotes collagen I and monocyte chemoattractant protein-1 expression: implications for the pathogenesis of HIV/hepatitis C virus-induced liver fibrosis. Hepatology 2010, 52:612-622.

39. Diepolder HM, Zachoval R, Hoffmann RM, Wierenga EA, Santantonio T, Jung MC, Eichenlaub D, Pape GR: Possible mechanism involving Tlymphocyte response to non-structural protein 3 in viral clearance in acute hepatitis C virus infection. Lancet 1995, 346:1006-1007.

40. Eckels DD, Tabatabail N, Bian TH, Wang H, Muheisen SS, Rice CM, Yoshizawa K, Gill J: In vitro human Th-cell responses to a recombinant hepatitis $C$ virus antigen: failure in IL-2 production despite proliferation. Hum Immunol 1999, 60:187-199.

41. Gigi E, Raptopoulou-Gigi M, Kalogeridis A, Masiou S, Orphanou E, Vrettou E, Lalla TH, Sinakos E, Tsapas V: Cytokine mRNA expression in hepatitis $C$ virus infection: $\mathrm{TH} 1$ predominance in patients with chronic hepatitis $\mathrm{C}$ and $\mathrm{TH} 1-\mathrm{TH} 2$ cytokine profile in subjects with self-limited disease. J Viral Hepat 2008, 15:145-154.

42. Nelson DR, Lau JY: Pathogenesis of hepatocellular damage in chronic hepatitis C virus infection. Clin Liver Dis 1997, 1:515-528, v.

43. Blackard JT, Komurian-Pradel F, Perret M, Sodoyer M, Smeaton L, St Clair JB, Chapman S, Taylor LE, Paranhos-Baccala G, Chung RT: Intrahepatic cytokine expression is downregulated during HCV/HIV co-infection. J Med Virol 2006, 78:202-207.

44. Sobue $\mathrm{S}$, Nomura T, Ishikawa T, Ito $\mathrm{S}$, Saso K, Ohara H, Joh T, Itoh M, Kakumu S: Th1/Th2 cytokine profiles and their relationship to clinical features in patients with chronic hepatitis $C$ virus infection. $J$ Gastroenterol 2001, 36:544-551.

45. Becker $Y$ : The changes in the Thelper 1 (Th1) and Thelper 2 (Th2) cytokine balance during HIV-1 infection are indicative of an allergic response to viral proteins that may be reversed by Th2 cytokine inhibitors and immune response modifiers-a review and hypothesi. Virus Genes 2004, 28:5-18.

\section{Pre-publication history}

The pre-publication history for this paper can be accessed here:

http://www.biomedcentral.com/1471-2334/12/102/prepub doi:10.1186/1471-2334-12-102

Cite this article as: Kang et al: Dynamic analysis of Th1/Th2 cytokine concentration during antiretroviral therapy of HIV-1/HCV co-infected Patients. BMC Infectious Diseases 2012 12:102.

\section{Submit your next manuscript to BioMed Central and take full advantage of:}

- Convenient online submission

- Thorough peer review

- No space constraints or color figure charges

- Immediate publication on acceptance

- Inclusion in PubMed, CAS, Scopus and Google Scholar

- Research which is freely available for redistribution

Submit your manuscript at www.biomedcentral.com/submit
Biomed Central 